\title{
ユーザ観察における動作パターンの自動分類によるデザイン課題発見*
}

村上 存 ${ }^{* 1}$, 種本 穣 $^{* 2}$

\section{Design Problem Detection by Automatic Classification of Behavior Patterns in User Observation}

\author{
Tamotsu MURAKAMI $^{* 1}$ and Minoru TANEMOTO \\ ${ }^{* 1}$ Univ. of Tokyo, Dept. of Mechanical Engineering \\ Hongo 7-3-1, Bunkyo-ku, Tokyo, 113-8656, Japan
}

In this paper, we propose a technology to automatically detect design problems of the product from user observation videos. In the proposed method, we attach color markers to necessary portions of a user and a product. Then we identify the coordinates of the markers in user observation videos by image analysis and color detection, compare the coordinates among markers qualitatively in every frame of the videos, and classify and encode user's postures in all frames of the videos. Through $\mathrm{N}$-gram analysis of qualitative posture sequences in the video, we classify and encode the user's behavior patterns as specific sequences of qualitative postures. We assume that the behavior patterns which frequently appear only when the user does not understand the usage of the product should possibly indicate some design problem such as incomprehensibility or difficulty for using. By conducting some experiments to detect such behavior patterns from user observation videos, we show the effectiveness of the proposed method.

Key Words : Usability, Observation, Behavior, Classification

\section{1. 緒言}

製品のデザインにおいて，潜在的なユーザの要求や製品の問題点などをデザイン課題として発見しそれを解決 することは, 新規性が高く競争力のある製品を実現する上で重要である.デザイン課題の発見手法の一つとして, ユーザへのアンケート調査があるが，ユーザ自身が意識していない問題については抽出できない可能性がある. それに対して，ユーザビリテイ設計などの分野で行なわれている，ユーザによる製品の操作を直接あるいは動画 を通して観察，分析し，問題点の発見，抽出を行う方法は，ユーザ自身が気づいていない潜在的な問題も発見で きる可能性がある点で有効な手法である(1).ユーザ観察を支援する研究として, 観察者が効率的に観察や記録を 行なえるツール(2)，ユーザ観察とそれに基づくインタビュー，分析を組み合せた「文脈における質問法」(3)などが ある. しかし，デザイン課題の気づきや発見を基本的に観察者の能力のみに依存する方法は，長時間の観察や多 数のユーザの比較などが必要になった場合に, 見落としや基準のブレなど確実性, 信頼性の確保が難しく, また 時間や労力を要するという問題があり, 課題発見自体に対する何らかのコンピュータ支援が望まれる.

筆者らは既報 ${ }^{(4)}$ において, 設計者が想定するユーザの動作を指定し, ユーザがその条件から外れた動作をした 箇所をユーザ観察動画から自動的に検出することにより，デザイン課題を発見する手法を報告した．本論文では そのアプローチをより一般化し，ユーザ観察動画において出現するユーザのさまざまな動作を，自動的にいくつ かのパターンに分類する方法を提案する，そして，ユーザが製品の使い方を理解している場合には出現せず，理 解していない場合のみ高頻度で出現する動作パターンを自動的に検出することによって，製品の使いにくさ，分

* 原稿受付 2011 年 4 月 14 日

*1 正員，フェロー，東京大学（干113-8656 東京都文京区本郷 7-3-1）

*2 東京大学 工学部

E-mail: murakami@mech.t.u-tokyo.ac.jp 
かりにくさなどのデザイン課題を抽出し，製品の設計改善に役立てる可能性を検証する.

\section{2. ユーザの姿勢の定性的分類}

\section{$2 \cdot 1$ ユーザ観察動画からの定性的姿勢情報の取得}

ユーザ観察動画から動作パターン情報を取得する方法としては，ユーザの身体や製品など観察対象の各部に付 したマーカの位置を画像から検出する方法や，身体の各部に付したセンサから情報を取得する方法により，身体

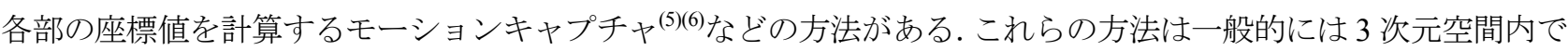
の身体各部の定量的で正確な座標值を取得し，正確な姿勢や動作を計測する目的で使用されることが多い．それ に対して本研究では, 後に述べるデザイン課題発見のための動作パターン分類に必要な程度の情報を取得できれ ばよいという考え方から処理を簡素化し，ユーザ観察動画からの定性的姿勢情報の取得を行なう.

具体的には，まず一般のモーションキャプチャと同様に，ユーザの身体や製品など観察対象の必要な位置に着 色マーカを付し，ビデオカメラにより動画を記録する. 空間の $Z$ 軸方向からのビデオカメラでは, $X-Y$ の 2 軸に ついての動画が取得できる，その動画から，画像認識による色識別を用いて各マーカの色領域の図心を計算し， 画面上での各マーカの座標值を取得する.

次に本研究では，取得した定量的な座標值そのものではなく，定性推論 ${ }^{(7)}$ と同様なアプローチにより，各マー カの座標值の各座標方向での定性的な大小関係を比較し，その定性的関係の組合せを一つの姿勢と定義して姿勢 ラベルを付寸. 定性的関係の組合せが同じであれば, 同じ姿勢であるとみなす. 例としてユーザの指先に緑 (G), 青（B)，赤（R）のマーカを付した場合を考える（図 1). 図 1 (a)の画像における各マーカの $X$ 座標, $Y$ 座標の大 小関係は, 記号 '>'，'='，'く'により図1(a)の表のとおりとなり，これを姿勢1'としてラベル付けする. これに対 して図 1 (b)の画像においては, 各マーカの座標值は定量的，詳細には図 1 (a) とは異なっているが，座標值の定性 的大小関係は図 1 (b) の表となり図 1 (a) と同一であるので，これも姿勢1'に分類される。一方，図 1 (c)の画像は マーカ R と B の $Y$ 座標の大小関係が姿勢1'とは異なるため，新たに姿勢2'のラベル付けがなされる.

マーカの位置の比較だけでなく, 例えば指の曲がり具合のような方向の情報も同様に定性的に処理する. 例え ば図 1 (d)に示すように, マーカ $\mathrm{m}_{\mathrm{a}}$ から $\mathrm{m}_{\mathrm{b}}$ に向かう方向と, マーカ $\mathrm{m}_{\mathrm{b}}$ から $\mathrm{m}_{\mathrm{c}}$ に向かう方向の定性的な関係は, 同一 (same), 反対 (opposite), 時計回り方向に相違 (clockwise), 反時計回り方向に相違 (counter-clockwise), の 4 つに分類できる. 分類の詳細度は目的に応じて設定可能であり, 例えば時計回りと反時計回りに $\pi / 2$ の方向 も分類の基準に加え，方向の定性的な関係を 8 つに分類することもできる.

以上の考え方によって本研究では，ユーザ観察動画の解析の初期段階でマーカの座標の数值から定性的姿勢分 類の記号に情報をコード化する.

\section{$2 \cdot 2$ 定性的姿勢分類ソフトウェアの実装}

本研究では，ユーザ観察動画から定性的姿勢情報の取得を行なう前記の処理をソフトウェアとして実装し，筆 者自身による基本実験を行なった. ソフトウェアはプログラム言語 $\mathrm{C}++$ で記述し, 動画処理ライブラリ OpenCV ${ }^{(8)}$ を用いた．色識別は動画の各フレームで取得した RGB 表色系の画像を，明暗による色変化に対してロバストな 認識が可能な色相, 彩度, 明度の 3 パラメータによる HSV 画像に変換して行う. 色相, 彩度, 明度の 3 つの值 に適切な閾值を設定して各マーカの色の領域をピクセル単位で取得し, 領域の図心を各マーカの座標值とする.
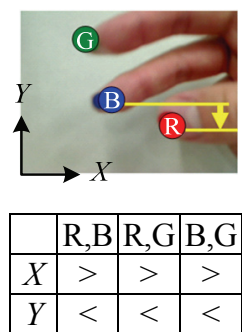

(a) Posture 1
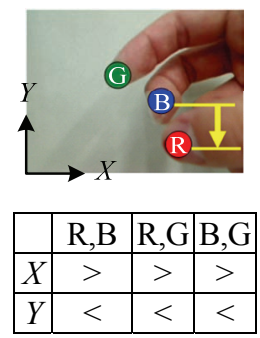

(b) Posture 1
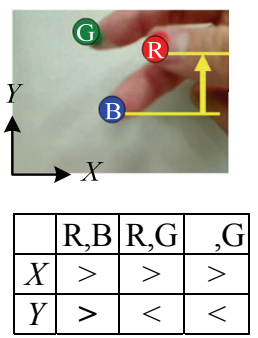

(c) Posture 2
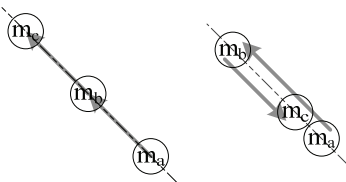

Same Opposite
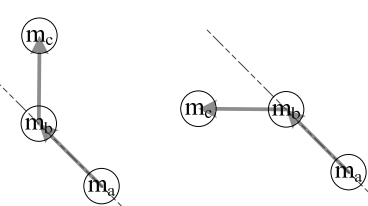

Clockwise Counter-Clockwise

Fig.1 Qualitative comparison of marker positions and directions 


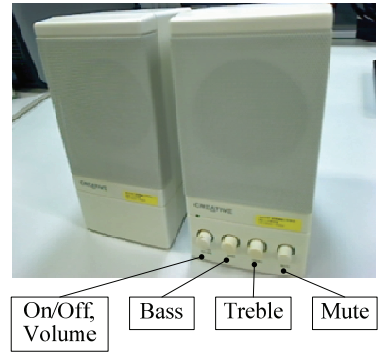

(a) PC speaker

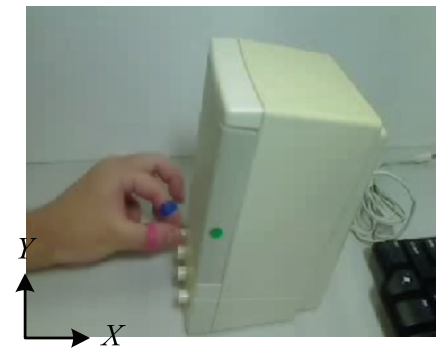

(b) Recorded video

Fig.2 Basic experiment of qualitative posture classification

Table 1 Markers for speaker operation

\begin{tabular}{|c|c|c|c|c|}
\hline Color & $H$ & $S$ & $V$ & Place \\
\hline Blue & $95-110$ & $100-255$ & $100-255$ & Index finger (left) \\
\hline Pink & $163-175$ & $100-255$ & $100-255$ & Thumb (left) \\
\hline Violet & $139-145$ & $60-255$ & $100-255$ & Index finger (right) \\
\hline Green & $60-75$ & $100-255$ & $100-255$ & Side (Speaker) \\
\hline
\end{tabular}

Table 2 Qualitative posture classification

\begin{tabular}{|c|c|c|c|c|c|c|c|}
\hline \multirow{2}{*}{ Axes } & \multicolumn{6}{|c|}{ Marker position comparison pair } & \multirow{2}{*}{ Posture label } \\
\hline & $\mathrm{B}, \mathrm{G}$ & $\mathrm{B}, \mathrm{P}$ & $\mathrm{B}, \mathrm{V}$ & G,P & $\mathrm{G}, \mathrm{V}$ & $\mathrm{P}, \mathrm{V}$ & \\
\hline \multirow{8}{*}{$X / Y$} &.$/$. & .1. &.$/$. & .1. &.$/$. &.$/$. & 0 \\
\hline & $</>$ &.$/$. & .1. &.$/$. &.$/$. &.$/$. & 1 \\
\hline & $</>$ & $>/>$ &.$/$. & $>/>$ &.$/$. &.$/$. & 2 \\
\hline & $</>$ & $>/>$ &.$/$. & $>/<$ &.$/$. &.$/$. & 3 \\
\hline & $</<$ &.$/$. &.$/$. & .1. &.$/$. &.$/$. & 4 \\
\hline & $</<$ & $>/>$ &.$/$. & $>/>$ &.$/$. &.$/$. & 5 \\
\hline &.$/$. & .1. & .1. & .1. & $>/<$ &.$/$. & 6 \\
\hline &.$/$. & .1. & .1. & .1. & $</<$ & .1. & 7 \\
\hline
\end{tabular}

\begin{tabular}{|c|c|c|c|c|c|c|c|}
\hline \multirow{2}{*}{ Axes } & \multicolumn{6}{|c|}{ Marker position comparison pair } & \multirow{2}{*}{ Posture label } \\
\hline & $\mathrm{B}, \mathrm{G}$ & $\mathrm{B}, \mathrm{P}$ & $\mathrm{B}, \mathrm{V}$ & G,P & $\mathrm{G}, \mathrm{V}$ & $\mathrm{P}, \mathrm{V}$ & \\
\hline \multirow{8}{*}{$X / Y$} & 1. & .1. & .1. & $>/>$ & .1. & .1 & 10 \\
\hline & $</<$ & $>/>$ & $>/<$ & $>/>$ & $>/<$ & $>/<$ & 11 \\
\hline & $<1<$ & $>1>$ & $>/>$ & $>1>$ & $>1>$ & $>/<$ & 12 \\
\hline & $</<$ & $>1>$ & $>/>$ & $>/>$ & $>/>$ & $>1>$ & 13 \\
\hline & $</>$ & $>/>$ & $>/>$ & $>/>$ & $>/>$ & $>/>$ & 14 \\
\hline & 1. & .1. & .1. & $>/>$ & $>/>$ & $>/>$ & 15 \\
\hline & 1. & .1. & .1. & $>/<$ & .1. & .1 & 16 \\
\hline & $>1<$ & .1. & .1. & .1. & .1. & .1. & 17 \\
\hline
\end{tabular}

本研究では基本確認実験として, Web カメラ（フレームサイズ $320 \times 240$ ピクセル，フレームレート $15 \mathrm{fps）を}$ 用いて，PC 用スピーカー（図 2 (a)）を操作する動画を取得した（図 $2(\mathrm{~b})$ )。 マーカは，ユーザの指には直接着色 可能なフェイス・ボディペイント絵具を，製品にはシールを用いた。青（被験者の左手人差し指），ピンク（同左 手親指)，紫（同右手人差し指），緑（スピーカーの前面寄り右側面）の 4 つを設定し，予備実験により色識別の ための色相，彩度，明度の值の範囲を決定した（表 1 ）.

被験者は，タスクとして次の a , b , c を，それぞれ 3 回ずつ行なった.

a . "Off/On Volume"（回す）を使ってスピーカーの電源を入れ，音量を大きくする.

b . "Bass"（回す）を使って低音を強めに調整する.

c. "Mute" (押す) を使って一時的に消音する.

以上の動画について，4つのマ一カそれぞれの $X$ 軸方向， $Y$ 軸方向の座標の大小比較による定性的姿勢分類を 行なった（方向による分類は行なっていない）。その結果，合計で表 2 に示す 18 通り（姿勢ラベル'0'〜'17'）の定 性的な姿勢分類が出現した． 2 つ座標值が等しいと判断する許容範囲を $1.0 \times 10^{-6}$ と狭く設定したため，'='は現 れていない，表中で.'が入っているのは，あるマーカが，撮影範囲に入っていなかったり手や製品の背後に隠れ て動画中に検出されず，そのマーカに関する比較が行なえなかった場合である.

\section{3. 姿勢の時系列としての動作パターン分類}

\section{$3 \cdot 1$ 姿勢の時系列としての動作}

以上により抽出した定性的姿勢は，動画の各フレームにおけるユーザの動作のスナップショットである. 本研 究では，定性的姿勢を時系列で並べたものを，ユーザの動作と考える. 2 ・2 で示した各タスクにおいて，表 2 の 
定性的姿勢を出現した時系列に並べたものを表 3 に示す．なお，この表では連続して出現した同一の定性的姿勢 （例えば，'1-1-1‥'）は一つ（'1'）にまとめている（すなわち，時間を圧縮し定性的姿勢の変化のみに注目して いる)。もちろん，時間はユーザによる動作の要因の一つであり，それを含めて分析する場合には，時間を圧縮せ ず処理する必要がある.

表 3 において, タスク a の 1 回目と 2 回目や, タスク c の 1 回目と 3 回目は, コード化された動作（出現する 定性的姿勢, その時系列）が類似したものとなっている. 実際にそれらの動画を確認すると, 被験者は類似した 動作を行なっていることが確認できた（図 $3(\mathrm{a})(\mathrm{b}))$. 一方，同じタスクであってもタスク c の 2 回目と 3 回目コ ード化された動作が異なっており, 実際にそれらの動画を確認すると, 被験者は異なった動作を行なっているこ とが確認できた（図 $3(\mathrm{c})$ ). 以上より, 本研究における定性的姿勢の分類と, その時系列による動作のコード化 が，動作の計測において有効である可能性を確認した.

\section{$3 \cdot 2 N$ グラムによる動作のパターン分類}

次に本研究では，計測された動作を，動作パターンに分類する．モーションキャプチャなどで動作を定量的な 3 次元座標值の変化として取得している場合は，座標值の数值的変化を特定のパターン（座標值の時系列グラフ のパターン）に分類する処理が行なわれる(9). それに対して本研究では，すでに座標值の定性的な比較による分 類により定性的姿勢がコード化されているため，そのコードの時系列（動作）に対して記号的な処理を行ない動 作パターンを抽出する. 具体的な方法として本研究では, 姿勢ラベルの時系列に対して $N$ グラム解析を行ない, 動作パターン（ $N$ 個の姿勢ラベルの時系列）を抽出する. $N$ グラムとは，ある文字列に対して， 1 文字ずつずら しながら $N$ 文字単位で文字を切り出し, キーワードなどを抽出する言語処理手法である(10). 例えば「工学部機械 工学科」という文字列に $N=2$ の $N$ グラム解析を行なうと, 「工学」,「学部」,「部機」,「機械」,「械工」, 「工学」, 「学科」が得られる. 多数の文書などを処理すると,「部機」「械工」など意味のない語句は低頻度のノイズとし て除去され,「工学」,「学部」,「機械」など意味のある語句が抽出できる.

Table 3 Sequences of qualitative postures

\begin{tabular}{|c|c|c|l|}
\hline Task & Trial & Frames & \multicolumn{1}{|c|}{ Posture sequence } \\
\hline \multirow{4}{*}{$\mathrm{a}$} & 1 & 97 & $0,1,2,3,2,3,2,3,2,3,2,3,2,4,0$. \\
\cline { 2 - 5 } & 2 & 115 & $0,1,3,2,3,2,3,2,4,0$. \\
\cline { 2 - 5 } & 3 & 115 & $0,4,1,3,16,3,2,3,2,3,16,3,2,3,2,3,2,3,2,1,0$. \\
\hline \multirow{3}{*}{$\mathrm{b}$} & 1 & 71 & $0,4,2,5,2,5,2,5,4,0$. \\
\cline { 2 - 5 } & 2 & 83 & $0,1,3,2,10,2,5,11,12,13,14,15,13,14,15,14,15,14,13,10,5,2,10,2,5,0$. \\
\cline { 2 - 4 } & 3 & 95 & $0,4,2,5,2,10,2,10,2,10,2,10,2,10,2,10,2,5,4,0$. \\
\hline \multirow{3}{*}{$\mathrm{c}$} & 1 & 83 & $0,6,7,8,9,8,7,0$. \\
\cline { 2 - 4 } & 2 & 97 & $0,4,5,4,5,4,0$. \\
\cline { 2 - 4 } & 3 & 105 & $0,6,7,8,9,8,9,8,7,0,17,0$. \\
\hline
\end{tabular}

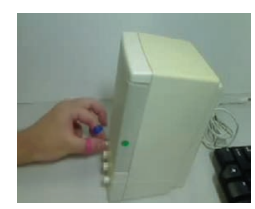

Task a-1 (a) Similar behaviors -> similar behavior codes (1)

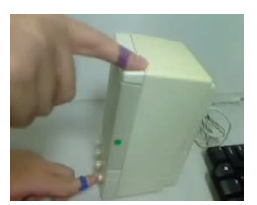

Task c-1

(b) Similar behaviors -> similar behavior codes (2)

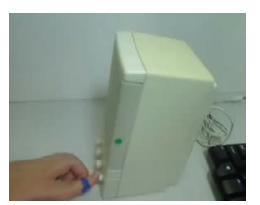

Task c-2

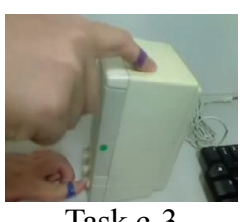

Task c-3

$\rightarrow$ different behavior codes

Fig.3 Basic experiment of qualitative posture classification

表 3 の姿勢の時系列に $N$ グラム解析 $(N=1,3)$ を適用した結果を図 4 に示寸. 例えば図 $4($ b $)$ において出現頻 度が高い'2-3-2'や'3-2-3'という動作パターンは, 図3(a), 表 2, 表3に現れているとおり, 被験者がダイヤルを回 すことによりピンクと緑のマーカの $Y$ 座標の大小関係が入れ替わる動作に該当する. また図 4 (b)の'2-10-2'や '10-2-10'という動作パターンは, 同じく図 3(a), 表 2, 表 3 において, ダイヤルを回すことにより, 姿勢2'から青 
のマーカが指の背後に隠れ検出できなくなった状態が姿勢10'にラベル付けされたものである. 以上の結果から， 定性的姿勢の時系列としての動作の出現頻度が容易に検出，比較できることが分かる.

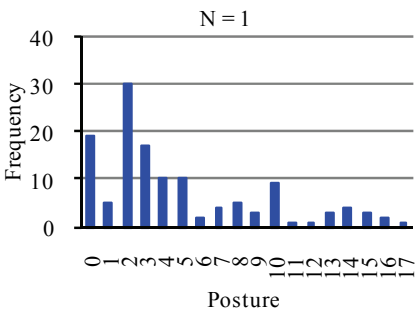

(a) $N=1$

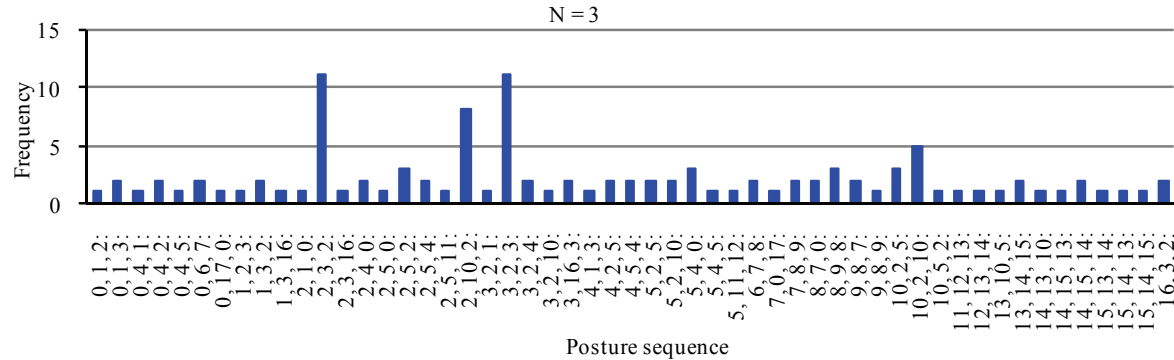

(b) $N=3$

Fig.4 N-gram analysis of speaker operation

\section{4. 理解時・非理解時の動作パターン比較によるデザイン課題発見}

本研究では，前記の $N$ グラム解析を用いて，ユーザ観察動画から動作のパターン分類を行ない，出現する動作 パターンの共通性，相違性などに注目寸ることにより，製品のわかりにくさ，使いにくさなどの顕在的，潜在的 なデザイン課題を発見することを試みる.

\section{$4 \cdot 1$ 理解時・非理解時の動作パターン比較}

いま，被験者が使い方を理解していない製品があると仮定する．その製品の使い方を説明せずに被験者にその 製品を使うタスクを与えると，ユーザは迷ったり試行錯誤をしながら，最終的にタスクを実行する（または実行 できずに終了する）と考えられる，次に，その被験者に連続して同じタスクを与えると，被験者はタスクの実行 方法を理解しているので，今度は迷いや試行錯誤なく，容易にタスクを実行できると考えられる．このような 2 回のタスク実行に出現する動作について，筆者らは次の仮説を立てた。

（1）非理解時（1 回目）と理解時（2回目）ともに出現する動作パターンは，そのタスクの実行に基本的に必 要な動作を表す。

(2) 非理解時のみ高頻度で出現し, 理解時には出現しない動作パターンは, 使いにくさや分かりにくさなど 何らかの顕在的，潜在的デザイン課題を示唆している可能性がある.

(3) 理解時の夕高頻度で出現し, 非理解時には出現しない動作パターンは, 理解していてはじめて考えつく, 可能になる，そのタスクの巧妙な実行方法，こつのようなものを示唆している可能性がある.

本研究では，具体的な製品を用いて，上記仮説(2)の検証を試みた。

\section{$4 \cdot 2$ 対象とする製品・タスク}

本研究では，図 5 に示すガスコンロの電池交換を対象として実験を行なった.

(a) 初期状態では操作パネルは本体ケースに収納され，前面プレートのみが見えている.

(b) 前面プレートを少し押すと，ばねで操作パネルが現れる．通常のコンロ操作はこの状態で行なう.

(c)＼cjkstart電池交換のためには，前面プレートのみをさらに前に倒し，操作パネルから分離する.

(d) 操作パネルのみを本体ケースに収納すると，電気ボックスの前面が現れる.

(e) 電池ボックスを手前に引き出す.

観察のためのマーカの色としては, 予備実験により安定して色識別が可能であった黄, ピンク, 緑, 青の 4 色 を用いた（表 4 ）.

操作は基本的に人差し指と親指で行なわれるので, 左 (右) 手の人差し指と親指に黄（ピンク）のマーカ $\mathrm{Y}(\mathrm{P})$ を付し, 検出した黄（ピンク）領域の図心を左（右）手の位置とした (図 6). また, 手が製品の左外側, 左内側, 中央，右内側，右外側のどこに位置するかを検出するため，前面プレートと操作パネルにそれぞれ青と緑のマー カ4つ（B，B2，B3，B4，G，G2，G3，G4）を付した（図6(a))。 なお，前面プレートと操作パネルが開閉して 
も，図６(a)中で青（緑）の４つのマーカ同士は同じ上下移動を行ない，左右には移動しないので，その条件をマ 一カ検出ソフトウェアに組み込んでおけば，同色のマーカを 4 付してもそれぞれを区別することができる．ま た，前面プレート，操作パネルが取り付けられている本体ケースは固定されているので，着色マーカを付さずに ソフトウェア処理で仮想的に K，K2，K3，K4 というマーカを設けている.

定性的姿勢分類を行なうために, 表 5 に示すように, マーカの 7 つの組については $X, Y, Z$ 各座標値の比較を 行ない, 18 の組については $X$ 座標值の比較のみ行なう. そのために, 図 7 に示すように 3 個のカメラを用い, そ れぞれの画像からマーカの $X$ 座標値, $Y$ 座標值, $Z$ 座標值の比較を行なう (図 7 )。実験は, マーカの色識別を容 易にするため，内側がシルバーグレーの暗幕で囲まれた簡易暗室において行なった.

\section{$4 \cdot 3$ ユーザ観察動画の取得と解析}

以上の設定に基づき，各被験者（東京大学の学生 10 名）に連続して次の 2 回のタスクを実行してもらった.

（1） 1 回目: 製品の操作方法を知らない状態で, 製品の初期状態（図 5 (a)）から電池交換を行なってもらう.

(2) 2 回目：1回目で操作方法を理解した状態で, 製品の初期状態（図 5 (a)）から再度電池交換を行なって もらう.

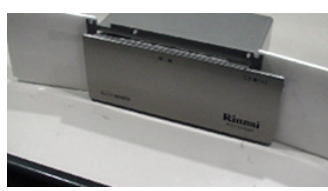

(a) Initial state

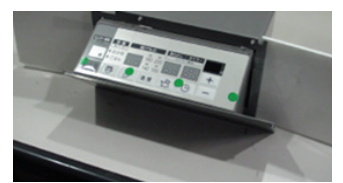

(b) Retract operation panel

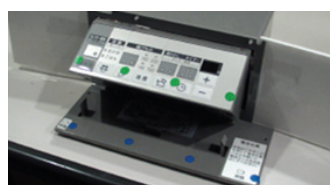

(c) Retract front plate

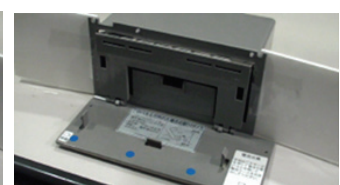

(d) Store only operation panel

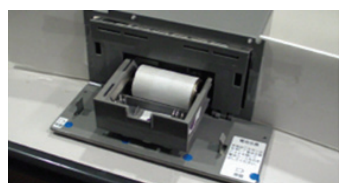

(e) Retract battery box under operation panel

Fig.5 Replacing battery to ignite gas cooker

Table 4 Markers for battery replacement

\begin{tabular}{|c|c|c|c|l|}
\hline Color & $H$ & $S$ & $V$ & \multicolumn{1}{|c|}{ Place } \\
\hline Yellow & $25-33$ & $200-255$ & $100-255$ & Thumb and index finger (left) \\
\hline Pink & $168-175$ & $130-255$ & $110-255$ & Thumb and index finger (right) \\
\hline Green & $66-82$ & $170-255$ & $70-255$ & Operation panel \\
\hline Blue & $99-115$ & $100-255$ & $50-255$ & Front plate \\
\hline
\end{tabular}

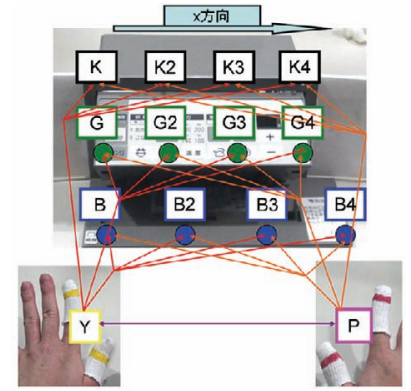

(a) Markers and their comparisons ( $X$ axis)

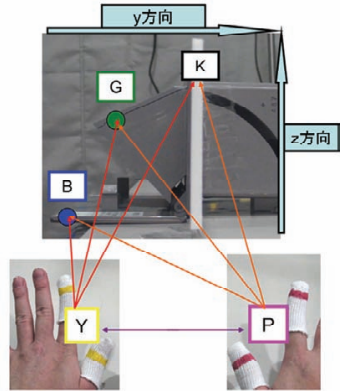

(b) Markers and their comparisons ( $Y$ and $Z$ axes)

Fig.6 Markers and their comparisons for battery replacement

Table 5 Marker comparisons for battery replacement

\begin{tabular}{|c|c|c|c|c|c|c|c|}
\hline Axes & \multicolumn{7}{|c|}{ Marker pair } \\
\hline$X-Y-Z$ & $(\mathrm{Y}, \mathrm{G})$ & $(\mathrm{Y}, \mathrm{B})$ & $(\mathrm{Y}, \mathrm{K})$ & $(\mathrm{P}, \mathrm{G})$ & $(\mathrm{P}, \mathrm{B})$ & $(\mathrm{P}, \mathrm{K})$ & $(\mathrm{Y}, \mathrm{P})$ \\
\hline \multirow{3}{*}{$X$ only } & $(\mathrm{Y}, \mathrm{G} 2)$ & $(\mathrm{Y}, \mathrm{B} 2)$ & $(\mathrm{Y}, \mathrm{K} 2)$ & $(\mathrm{P}, \mathrm{G} 2)$ & $(\mathrm{P}, \mathrm{B} 2)$ & $(\mathrm{P}, \mathrm{K} 2)$ & \\
& $(\mathrm{Y}, \mathrm{G} 3)$ & $(\mathrm{Y}, \mathrm{B} 3)$ & $(\mathrm{Y}, \mathrm{K} 3)$ & $(\mathrm{P}, \mathrm{G} 3)$ & $(\mathrm{P}, \mathrm{B} 3)$ & $(\mathrm{P}, \mathrm{K} 3)$ & - \\
& $(\mathrm{Y}, \mathrm{G} 4)$ & $(\mathrm{Y}, \mathrm{B} 4)$ & $(\mathrm{Y}, \mathrm{K} 4)$ & $(\mathrm{P}, \mathrm{G} 4)$ & $(\mathrm{P}, \mathrm{B} 4)$ & $(\mathrm{P}, \mathrm{K} 4)$ & \\
\hline
\end{tabular}


操作の様子をカメラ 3 台で撮影して動画（15fps）に記録した. 各被験者がタスクを完了するまでの各動画のフ レーム数を表 6 に示す. 各被験者とも，1 回目は操作方法が分からず試行錯誤したのに対し，2 回目は操作方法 を理解しているため, 2 回目のフレーム数 (時間) が小さくなっている.

これら 20 の動画について, 動画フレーム毎に被験者によらず同じ定性的姿勢分類には同じ姿勢ラベルを付与す る分類を行なった. その結果, $X$ 軸方向のみの関係の組合せ 143 通り (姿勢ラベル $\mathrm{x} 0 \sim \mathrm{x} 142$ ),$Y$ 軸方向のみの関 係の組合せ 88 通り（姿勢ラベル $\mathrm{y} 0 \sim \mathrm{y} 87$ )， $Z$ 軸方向のみの関係の組合せ 114 通り（姿勢ラベル $\mathrm{z} 0 \sim \mathrm{z} 113$ )，X-Y-Z 各軸の関係を総合した場合は 2197 通り（姿勢ラベル xyz0〜xyz2196）が出現した.

次に, 20 の動画に出現した姿勢の時系列について, 迷いなどにより姿勢 $P_{\mathrm{A}} \rightarrow P_{\mathrm{B}} \rightarrow P_{\mathrm{A}}$ のように後戻りした場合 を表現できる最小の数である $N=3$ を用いて $N$ グラム解析により各動作パターンの出現頻度を求めた. それを 1 回目（操作方法非理解時）と 2 回目（理解時）の関係としてプロットした結果を図 8 に示寸. 図中にプロット

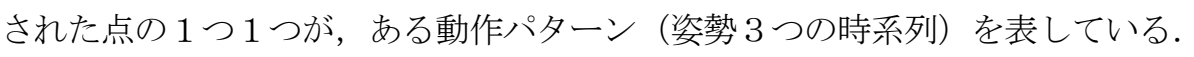

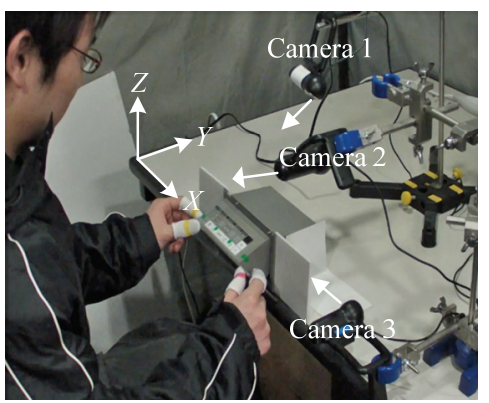

(a) Cameras for user observation

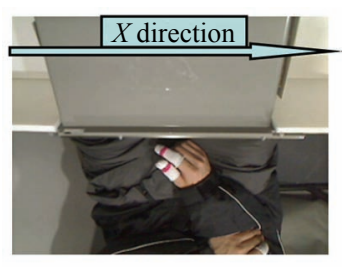

(b) Camera 1

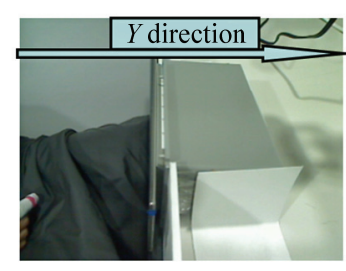

(c) Camera 2

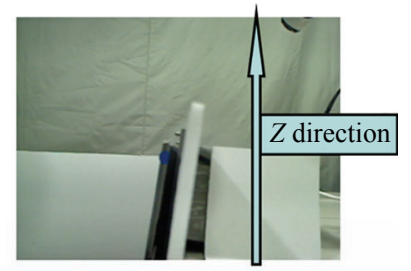

(d) Camera 3

Fig.7 Equipment for user observation experiment

Table 6 Video frames for battery replacement task

\begin{tabular}{|c|c|c|c|c|c|c|c|c|c|c|}
\hline & \multicolumn{10}{|c|}{ Subject } \\
\cline { 2 - 11 } & 1 & 2 & 3 & 4 & 5 & 6 & 7 & 8 & 9 & 10 \\
\hline Trial 1 & 1380 & 510 & 390 & 1095 & 270 & 720 & 645 & 960 & 450 & 495 \\
\hline Trial 2 & 135 & 75 & 45 & 90 & 105 & 120 & 60 & 135 & 120 & 60 \\
\hline
\end{tabular}

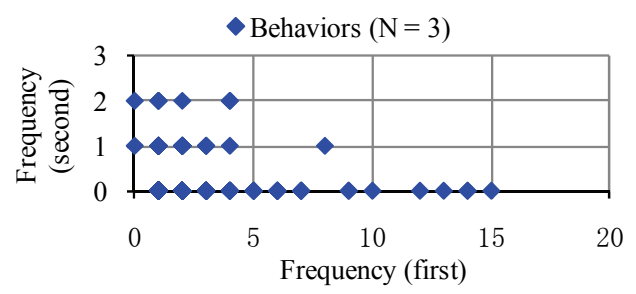

Fig.8 Behavior pattern frequencies when non-understanding/understanding the usage

ここで，4・1の仮説(2)に基づき， 1 回目（操作方法非理解時）には出現頻度が高く, 2 回目（理解時）には出 現頻度が低い動作パターンについて分析を行なった結果の一部を表 7 に示す. 表 7 の動作パターンを構成する姿 勢ラベル $(X$ 方向）の内容を表 8 によめる. 表 8 は, 被験者の左手, 右手に付したマーカ $\mathrm{Y}$, マーカ $\mathrm{P}$ と, 製 品に付したマーカ $\mathrm{G} \sim \mathrm{G} 4$ ， マーカ $\mathrm{B} \sim \mathrm{B} 4$ ， マーカ $\mathrm{K} \sim \mathrm{K} 4$ （仮想的）の $X$ 座標の大小を比較したもので，表中の 3 つの姿勢ラベルすべてに共通の内容は灰色で網掛けされている. 例えば姿勢ラベル $\mathrm{x} 15$ ではマーカ $\mathrm{P} の X$ 座標 はマーカ K4 より大きいのに対し, 姿勢ラベル x 23 では小さい. また, 比較される一方または両方のマーカが画 像から検出されない場合は, 記号 '.'を記してある.

表 7 で，［非理解時の頻度，理解時の頻度 $]=[14,0]$ の動作パターン x15 - x $23-\mathrm{x} 15$ は，表 8 およびこの動 作パターンが出現した箇所の動画から, 右手のマーカ P が製品右端のマーカ K4 付近を往復していることを示寸 ことが分かる (図 9(a)). 同様に, 頻度 $[9,0]$ の動作パターンx15 - x21 - x15 は, 表 8 およびこの動作パターン 
が出現した箇所の動画から, 左手のマーカ Y が製品左端のマーカ K 付近を往復していることを示すことが分かる

(図 9(b))。これらはいずれも迷って先に進めない状況を表しており, 実際に電池交換を行なおうとすると，日 常的な操作である操作パネルを引き出す動作（図 5 (b)）までは問題なく進めても，そこから前面プレートを引き 剥がすように前に倒す操作（図５(c)）に気づくのに時間を要する可能性があることが分かる.

以上の結果から，非理解時には出現頻度が高く理解時には出現頻度が低い動作パターンを自動的に検出する本 研究の手法により，人間がユーザ観察動画を長時間注意深く観察しなくても，分かりにくさなど製品のデザイン 課題が出現している箇所をビデオ中から検出できる可能性が確認できた.

Table 7 Behaviors suggesting possible design problems.

\begin{tabular}{|c|c|c|}
\hline Frequency (first) & Frequency (second) & Behavior (Posture sequence, $N=3$ ) \\
\hline 14 & 0 & $\mathrm{x} 15-\mathrm{x} 23-\mathrm{x} 15$ \\
\hline 9 & 0 & $\mathrm{x} 15-\mathrm{x} 21-\mathrm{x} 15$ \\
\hline
\end{tabular}

Table 8 Examples of qualitative postures in $X$ coordinate during the task

\begin{tabular}{|c|c|c|c|c|c|c|c|c|c|c|c|c|c|c|c|c|c|c|c|c|c|c|c|c|c|c|}
\hline \multirow{2}{*}{$\begin{array}{l}\text { Posture label } \\
\text { in } X\end{array}$} & Marker 1 & \multicolumn{13}{|c|}{$\bar{Y}$} & \multicolumn{12}{|c|}{$P$} \\
\hline & Marker 2 & $\mathrm{P}$ & $\mathrm{G}$ & $\mathrm{B}$ & G2 & G3 & G4 & B2 & B3 & B4 & $\mathrm{K}$ & K2 & $\mathrm{K} 3$ & K4 & $\mathrm{G}$ & $\mathrm{B}$ & G2 & G3 & G4 & B2 & B3 & \begin{tabular}{|l|} 
B4 \\
\end{tabular} & $\mathrm{K}$ & K2 & K3 & $\mathrm{K} 4$ \\
\hline $\mathrm{x} 13$ & & $<1$ & $<$ & . & $<$ & $<$ & $<$ & . & . & . & $>$ & $<$ & $<$ & $<$ & $>$ & . & $>$ & $>$ & $>$ & . & . & . & $>$ & $>$ & $>$ & $>$ \\
\hline $\mathrm{x} 2$ & & $<$ & $<$ & . & $<$ & $<$ & $<$ & . & • & . & $<$ & $<$ & $<$ & $<$ & $>$ & . & $>$ & $>$ & $>$ & . & . & . & $>$ & $>$ & $>$ & $>$ \\
\hline $\mathrm{x} 2$ & & $<$ & $<$ & . & $<$ & $<$ & $<$ & . & . & . & $>$ & $<$ & $<$ & $<$ & $>$ & . & $>$ & $>$ & $>$ & . & . & . & $>$ & $>$ & $>$ & $<$ \\
\hline
\end{tabular}

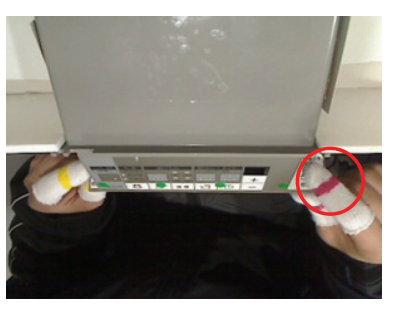

(a) Wandering right hand

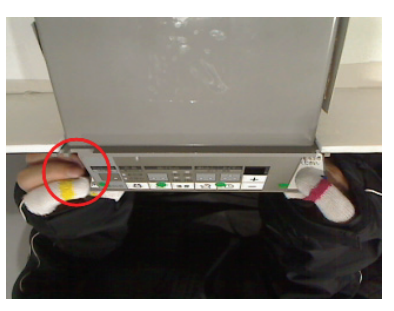

(b) Wandering left hand

Fig.9 Detected behavior patterns indicating design problem

\section{5. 議論}

\section{$5 \cdot 1$ 本手法の特長}

モーションキャプチャにより動作情報を定量的に取得する手法に比較して，本手法はカメラの台数に応じた解 析が行なえる柔軟性が特徵である. 対象や状況により複数台のカメラの使用が困難な場合であっても, 例えば 1 台のカメラでもそれなりの分析を行なえる可能性がある.

本手法は，次の段階的な手順で構成される.

(i) 動画からマーカを識別する.

(ii) 画像中のマーカ座標を取得する.

(iii) マーカ同士の座標值の定性的な関係の組合せにより，姿勢をコード化するそその結果，ユーザの動作が 姿勢コードの時系列で表現される.

(iv) ユーザの動作パターンを $N$ グラム解析する.

(v) 例えば製品使用法の理解時と非理解時の出現動作の共通性や相違性から，デザイン課題を発見する.

本論文では，(i)〜(v)について自動的に（ただしデザイン課題の発見自体は人間による）行なったが，各手順は 独立しているので，例えばモーションキャプチャを想定しておらず，被験者や製品にマーカが付されていない 1 台のカメラによる過去の動画であっても，画像中の被験者や製品の注目部位を人手により指示し，それをマーカ とみなして手順(ii)以降を自動的に行なうなどの実施も可能である. 


\section{$5 \cdot 2$ 関連する研究}

本論文に関連する研究として，設計者と初心者ユーザの操作時間を比較することで，設計者が自身とユーザの 相違を認識し，ユーザにとって使いやすい設計を実現する方法が報告されている ${ }^{(11)}$. 本論文の手法でも，操作の 熟練者と初心者など，異なるユーザ群の比較を行なう点では同じであるが，単なる時間だけでなく，動作パター ンの内容についての比較が行なえる点で，より深いデザイン課題を発見できる可能性がある.

筆者らは，光造形法等で作成される透明な製品笚体モデルの内側から小型ビデオカメラで動画を取得，解析す る, 内部動画解析モックアップ技術を報告している ${ }^{(12)}$. 本論文の手法は内部動画解析に用いることも可能であり, 使用時に位置や姿勢が動的に変化し外部設置したビデオカメラでは動きのトラッキングが困難な携帯機器に関し てや，外側からの動画では情報を取得しにくい，ユーザによる携帯型製品の詳細な使用状態（持ち方の微妙な変 化，操作に使用した手指の区別など）からデザイン課題を発見することも可能になると考えられる.

\section{$5 \cdot 3$ 本手法の課題}

本研究の課題のいくつかを次に示す.

・ 現在の分析では連続する同一の定性的姿勢は時間を圧縮して変化パターンのみを解析しているが，実際 のユーザビリティ評価では時間の要因も重要であり，それを含めた分析を行なう必要がある.

- 本論文の $4 \cdot 1$ で仮説として挙げた, 理解時・非理解時とも高頻度で出現する動作パターンの意味, 理解 時に高頻度で非理解時に低頻度な動作パターンの意味について分析を行なうことによって，より多くの デザイン課題発見を行なえる可能性がある.

・現在は色でマーカを識別しているが，より複雑な問題を分析するために多数のマーカが必要な場合，多 くの色を安定して識別する方法や，色以外の情報で多数のマーカを識別する方法が必要となる.

・ 本論文の 4 ・3 では, $X-Y-Z$ 軸を総合すると非常に多くの数の定性的姿勢の分類がなされる. 被験者や製 品のどこにマーカを付し，どのマーカ同士をどの軸方向で比較するかによって，分析できる問題の内容 が決まってくる．分析の目的に応じた必要十分な分類が得られるような，マーカ設定方法を定式化する ことが望まれる。

\section{6. 結 語}

本研究の結論を以下にまとめる.

・ 複数のマーカの定性的な位置/方向関係によってユーザ観察の被験者の姿勢を定性的に分類しコード化 する手法を提案した.

・ 姿勢コードの時系列化およびその $N$ グラムにより, 動作をコード化, パターン分類する手法を提案した.

・ ユーザ観察において，ユーザが製品の使い方を理解していない場合に高頻度で出現し理解している場合 には出現しない動作パターンを検出することにより，分かりにくさ，使いにくさなどのデザイン課題発 見を行なえる可能性を，実験により示した。

本研究は東京大学大学院工学系研究科機械工学専攻デザインイノベーション社会連携講座において, 藤垣善昭 氏（リンナイ株式会社開発本部）のご協力，ご助言を得て行なわれた．ここに謝意を表する.

\section{文献}

(1) 松波晴人, 山岡俊樹, ”家庭用機器のユーザリクアイアメント抽出手法の比較研究”, デザイン学研究, Vol.52, No.2 (2005), pp.31-40.

(2) Qiang, Y., Sakuragawa, S., Suzuki, T., Tamura, H., and Kurosu, M., "New Data Logging Software Effectively Implement Observation Records for Usability Testing", Proceedings of 15th Triennial Congress of the International Ergonomics Association, Vol.1 (2003), pp.275-278. 
（3）小幡明彦，高本康明，木島裕二，國藤進，杉山公造,”製品担当者によるユーザ現場観察の有効性評価”，情報処理 学会研究報告, Vol.2001, No.32 (2001), pp.13-18.

(4) 樋口麻里子, 村上存, ”ユーザ観察ビデオからの設計／デザイン課題の取得の試み”, ヒューマンインタフェースシ ンポジウム 2009 論文集，(2009), pp.191-194.

(5) 持丸正明,”身体の運動計測技術の動向”，計測と制御，Vol.36，No.9 (1997), pp.609-614.

(6) Vlasic, D., Adelsberger, R., Vannucci, G., Barnwell, J., Gross, M., Matusik, W., and Popovic, J., "Practical Motion Capture in Everyday Surroundings", ACM Transactions on Graphics, Vol. 26, No. 3 (2007), Article 35 (9 Pages).

(7) 西田豊明, 定性推論の諸相, (1993), p.26, 朝倉書店.

(8) 奈良科学先端技術大学院大学 OpenCV プログラミングブック製作チーム, OpenCV プログラミングブック, (2007), 毎日コミュニケーションズ.

(9) Barbic, J., Safonova, A., Pan, J., Faloutsos, C., Hodgins, J.K., and Pollard, N.S., Segmenting Motion Capture Data into Distinct Behaviors, Proceedings of Graphics Interface 2004, (2004), pp.185-194.

(10) 言語処理学会編, デジタル言語処理学事典, (2010), p.291, 共立出版.

(11) 鱗原晴彦, 古田一義, 田中健一, 黒須正明, ” 設計者と初心者ユーザの操作時間比較によるユーザビリティ評価手 法”，ヒューマンインタフェースシンポジウム 1999 論文集，(1999), pp.537-542.

(12) 村上存, 中野道樹, ”光造形モックアップと内部カメラによるインタフェース機能模擬およびユーザビリティ・デ 一タ自動計測”，日本機械学会論文集 C 編，Vol.73，No.727 (2007)，pp.927-934. 